University of South Florida

DIGITAL COMMONS

Digital Commons @ University of

@ UNIVERSITY OF SOUTH FLORIDA

South Florida

1995

\title{
The Politics And Processes Of Scholarship
}

Joseph M. Moxley

University of South Florida Department of English, moxley@usf.edu

Lagretta T. Lenker

Follow this and additional works at: https://digitalcommons.usf.edu/eng_facpub

\section{Scholar Commons Citation}

Moxley, Joseph M. and Lenker, Lagretta T., "The Politics And Processes Of Scholarship " (1995). English Faculty Publications. 164.

https://digitalcommons.usf.edu/eng_facpub/164

This Book Chapter is brought to you for free and open access by the English at Digital Commons @ University of South Florida. It has been accepted for inclusion in English Faculty Publications by an authorized administrator of Digital Commons @ University of South Florida. For more information, please contact digitalcommons@usf.edu. 


\section{Recent Titles in}

Contributions to the Study of Education

Archetypal Forms in Teaching

William A. Reinsmith

Labor Relations in Education: An International Perspective Bruce S. Cooper, editor

The Emerging Worldwide Electronic University

Parker Rossman

A New History of Educational Philosophy

James S. Kaminsky

Does College Make a Difference?: Long-Term Changes in Activities and Attitudes William E. Knox, Paul Lindsay, and Mary N. Kolb

Assessing What Professors Do: An Introduction to Academic Performance Appraisal in Higher Education

David A. Dilts, Lawrence J. Haber, and Donna Bialik

Encounters with Difference: Student Perceptions of the Role of Out-of-Class

Experiences in Education Abroad

Michael R. Laubscher

Public School Reform in Puerto Rico: Sustaining Colonial Models of Development José Solís

Diversifying Historically Black Colleges: A New Higher Education Paradigm Serbrenia J. Sims

Socialization and Education: Essays in Conceptual Criticism

Wolfgang Brezinka

The Importance of Learning Styles: Understanding the Implications for Learning, Course Design, and Education

Ronald R. Sims and Serbrenia J. Sims

Achieving Racial Balance: Case Studies of Contemporary School Desegregation Sondra Astor Stave

\section{THE POLITICS AND PROCESSES OF SCHOLARSHIP}

\section{Edited by \\ JOSEPH M. MOXLEY \\ and \\ LAGRETTA T. LENKER}

Foreword by R. Eugene Rice

Contributions to the Study of Education, Number 66

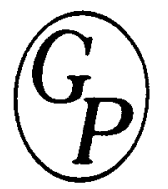

GREENWOOD PRESS

Westport, Connecticut • London 


\title{
Introduction
}

\author{
Joseph M. Moxley and Lagretta T. Lenker
}

Across disciplines, faculty are talking about the redefinition of scholarship. Faculty in humanities and social science departments have been particularly vocal ahout ways to improve both the academic reward system and the product of that system. For all around us in both our personal and professional lives, we are confronted with significant problems-the public schools' inability to teach; violent crime; the deterioration of our environment; overpopulation; racism and ethnic cleansing - that could be lessened, perhaps even solved, by the collective attention of academe. Unfortunately, however, American colleges and universities typically do not reward faculty for engaging in research or scholarship that address these kinds of problems.

Academic institutions have traditionally favored a narrow range of intellectual pursuits. Tenure and promotion committees at many universities and colleges devalue research that integrates and synthesizes theories across disciplines, trade books, textbooks, or pedagogical articles. Traditional committees and department chairs, when they assume a mentoring role, typically encourage faculty to write for specialists and to avoid writing essays or books for broad audiences. We can trace the source of this narrow conception of scholarship to approximately 1815 to 1915, when American scholars imported Germany's system of research-based graduate study and the associated ideal of "pure" research (Connors, 1991). Since the early nineteenth century, universities and colleges have encouraged faculty to ignore the problems of "society, politics, morality, and religion, even from the classroom itself, and [remove themselves] during most of their waking hours from their fellow men" (Lawrence R. Veysey, quoted in Connors, 60). Although many professional organizations, scholars, and even accrediting organizations are beginning to challenge this narrow view of scholarship, the legacy of privileging research and theory for specialists over pedagogy and other applied concerns still guides the missions of many American universities.

Rather than privileging basic research or theoretical studies, critics of higher education argue that universities should equally value applied research, 
community service, and teaching. R. Gene Rice, Richard Gebhardt, Robert Diamond, Ernest Boyer, Clara Lovett, and Russell Edgerton, for example, have persuasively argued that universities and colleges should reconstruct their perception of scholarship as "pure" and reconsider their perception of undergraduate teaching as atheoretical. Additional support for redefining scholarship can also be found in postmodern theories. Postmodernists have rejected the modernists' faith in objectivity and foregrounded the ideological nature of scholarship and teaching. Rather than perceiving scholarship (or teaching) as the objective illumination of the truth, academicians have embraced the concepts of multiple truths, of situational knowledge, of valuing the striving for truths over the expectation of uncovering a truth that transcends culture and the evolution of time and knowledge. Postmodernists have challenged grand narratives-such as Freudianism and Darwinism - because these narratives assume that human beings share universal characteristics and because these theories overlook or downplay the effects of culture, class, gender, or socioeconomic status on the development and constitution of self. As postmodern theories have transformed academic disciplines, professors have exposed the myth of disinterested science. If meaning is socially constructed by members of a discourse community, then researchers and scholars should avoid generalizing or depicting knowledge as limited to specific communities. By validating the subjective nature of interpretation, postmodern theorists have provided the theoretical ground for qualitative research methodologies and the personal essay. In short, no one form of scholarship is inherently superior; instead, all scholarship is valued by the standards of its discourse community.

While the foundations of scholarship have been battered by reformers, perhaps the greatest challenge, the challenge that truly will redefine scholarship and transform the academic reward system, lies ahead in the networked, electronic community. Thanks to the possibilities created by the Internet and multimediaauthoring software, some professors have even called for the end of scholarship as we know it. After all, the Internet permits the immediate distribution of knowledge. Via electronic conferencing programs, scholars throughout the world can engage in real-time discussions about issues of importance to them. Working collaboratively on listservs, scholars can extend the conversations in their disciplines at a pace that traditional scholarly journals cannot. If we can distribute our ideas within nanoseconds, if we can create a homepage on the World Wide Web to store our favorite essays, books, and hypermedia software, why do we need to wait months, even years, to produce books in text-bound form? Indeed, how can we not create a new genre of scholarship-one that is more immediate, more collaborative-than current modes of scholarship now that we can use Internet browsers to access information stored in computers throughout the world; now that we can engage in extended, text-based discussions with other colleagues at other institutions on listservs and via E-mail; and now that we can use multimedia-authoring software to develop documents that contain audio, visuals, and movies.

Reformers will certainly face obstacles to redesigning the faculty reward system so that professors are rewarded for monitoring listservs, authoring multimedia software, and organizing electronic conferences. In this late age of print, some technophobics will argue that the printed book is superior to the multimedia book. Some will argue that listservs serve neophytes who are more concerned with socializing than with debating serious intellectual questions or critiquing a canon. Ultimately, however, the new intellectual frontier creates too many possibilities for innovative faculty to ignore. If academic institutions hope to be honored and supported, if they acknowledge their responsibilities for educating students, then faculty will be encouraged to participate in computerrelated research and computer-assisted instruction. Academics just cannot stick their heads in the sand on this issue-that is, if they hope to come up for air.

Along with heated discussions about ways to improve the faculty reward system, professors across disciplines have problematized their roles, questioning, for example, whether they should serve as agents of social change or as representatives of the military-industrial complex. Some faculty believe they should serve as public intellectuals. Rather than writing for a narrow group of specialists in academic journals, they hope to influence public opinion and policies by publishing trade books and articles in magazines and the op-ed pages of daily newspapers (Scott, 1994).

Clearly, current methods of defining and rewarding scholarship are not working, and the role of the professoriate will be forced to change, thanks to modern technologies and thanks to major social, economic, and environmental problems that our world population faces. Recent surveys of faculty attitudes demonstrate that faculty are discouraged from pursuing the practical implications of their scholarship, from conducting research related to their teaching, and from working collaboratively to improve their institutions, professional organizations, or communities (Boyer, 1990; Gray et al., 1994; Sykes, 1988). Present estimates of faculty productivity suggest that 10 to 15 percent of the professoriate account for the bulk of what is published (Boice and Jones, 1988; Jalongo, 1985). In turn, when the Carnegie Foundation for the Advancement of Teaching surveyed 5,000 faculty throughout the United States (1989), it discovered that few faculty had published many articles or books: 13 percent of the faculty members at four-year institutions had published no essays, 30 percent had published one to five essays, and 49 percent had written or edited no books. In turn, at two-year institutions, 52 percent had published no articles and 69 percent had written or edited no books (Boyer, 1990).

While creative endeavors cannot be reduced to quantitative unit-one major book can transform a discipline in ways a dozen minor books cannot-we clearly have some evidence that faculty could be much more productive. Those of us who provide faculty development programs understand that professors need 
training in writing; marketing essays, books, and grant proposals, Internet browsers, multimedia-authoring software, and electronic conferencing software. Certainly, if institutions provided more support programs for creative endeavors, faculty would be more creative and would be more likely to share their ideas in refereed journals and to work collaboratively.

To help our colleagues find their voices as scholars and teachers, we need to do more than provide useful faculty-development workshops: more professors would realize their creative potential if academic institutions rewarded faculty for conducting applied forms of scholarship or research related to teaching. Few faculty are in a position to routinely discover new knowledge, which may explain why so much scholarship is so jargon-ridden that only a few specialists can read (or care to read) it. Yet faculty can be creative in a range of ways-that is, by conducting research related to their teaching, synthesizing and integrating others' scholarship, and translating scholarship to less specialized audiences.

Also, unmistakably, public dollars that fuel major portions of academic research will go to projects perceived as having direct benefits to our society and economy. In this era of streamlining government and budgets, the academic community must demonstrate a profound value-added relationship between scholarship and quality of social life. If today's academics fail to manage this debate, surely future scholars will suffer as business and industry assume the lead in this technology and information revolution. Academic turf wars, compensation/rewards systems, and even academic freedom will become obsolete issues unless the academy firmly establishes itself as the most efficient, effective, and responsible defenders and producers of knowledge-electronic and otherwise. To make this claim, we must maintain order in our own metaphorical house. This volume, it is hoped, contributes to that elusive process.

\section{THE POLITICS AND PROCESSES OF SCHOLARSHIP}

In March of 1994, we held a conference at the University of South Florida titled The Politics and Processes of Scholarly Publishing. Over a four-day period, provosts, editors, publishers, and faculty-development specialists debated ways to define scholarship and improve the faculty reward system. Over lunches and dinners, keynote and plenary speeches, panel presentations, and open-ended discussions, we discussed many of the tough questions that contemporary faculty and university administrators are debating within the higher education community, such as

- When determining tenure, promotion, and merit pay, how much weight should universities and colleges ascribe to the scholarships of discovery, integration, application, and teaching?

- Will giving additional weight to the scholarships of integration and application inspire more faculty to conduct research and publish their results?
- What institutional and academic barriers have kept faculty-development specialists and administrators from changing the faculty reward system?

- How does one's class, race, and gender affect what gets published or funded and who gets promoted?

- How can we improve the peer-review process and the selection process for choosing editors and members of a journal's editorial board?

- How will the Internet, online databases, and electronic journals impinge on the creative endeavors of faculty, notions of intellectual property, and promotion criteria?

- What innovative faculty initiatives can colleges and universities develop to help faculty find their voices as researchers, scholars, and teachers?

Even though these conference participants represented a variety of disciplines and academic institutions from throughout United States, Canada, Jamaica, and Africa, their presentations and discussions made it clear that they shared many similar ideas about improving higher education.

Now, several years later, we present this book as a sample of our discussions, albeit a more polished sample of our ideas. In a broad sense, this book is about who we are and who we want to be. Written for faculty and faculty-development administrators, this book is about the changing, evolving responsibilities of the professoriate in a postmodern, networked world. This book analyzes ways to redefine scholarship, suggested alternatives to improve the academic reward system, explores the impact of technology on scholarship, and presents innovative faculty-development initiatives.

\section{REFERENCES}

Boice, Robert, and Ferdinand Jones. "Why Academicians Don't Write." Journal of Higher Education 4: 2 (Fall 1988): 4-46.

Boyer, Ernest. Scholarship Reconsidered: Priorities of the Professoriate. Princeton, J.J.: Carnegie Foundation for the Advancement of Teaching, 1990.

Connors, Robert. "Rhetoric in the Modern University: The Creation of an Underclass." The Politics of Writing Instruction: Postsecondary. Gen. ed. Charles Schuster. Portsmouth, N.H.: Boynton/Cook Publishers, 1991. 55-84.

Gray, Peter J., Robert C. Froh, and Robert M. Diamond. "Myths and Realities." Institutional Priorities and Faculty Rewards. Syracuse, N.Y.: Syracuse University, Center for Instructional Development, 1994.

Jalongo, Mary Renck. "Faculty Productivity in Higher Education." Educational Forum 49 (Winter 1985): 17-182.

Scott, Janny. "More Intellectuals Writing for Public Instead of Fellow Scholars." New York Times News Service, August 8, 1994.

Sykes, Charles J. ProfScam: Professors and the Demise of Higher Education. Washington, D.C.: Regnery Gateway, 1988. 